\title{
PERMANENT TRANSMISSION OF ENDOPARASITES IN LARGE HERDS OF CATTLE
}

\author{
J. BEJŠOVEC \\ Department of Animal Physiology and Zoology, \\ University of Agriculture, 16521 Praha
}

Received April 14, 1990

\begin{abstract}
Bejšovec, J.: Permanent Transmission of Endoparasites in Large Herds of Cattle. Acta vet. Brno, 60, 1991: 205-212.

Calving houses were found to be contaminated with endoparasites by the first crop of pregnant cows arriving in the new premises. No significant differences were found in the incidence of endoparasite species between new and old calving houses by analysis of variance. The proportions of dams excreting coccidial oocysts and gastroenteronematode eggs were $97.2 \%$ and $38.1 \%$, respectively. The calves became infected with small numbers of endoparasites. After transfer to large-capacity calf houses coccidia and gastroenteronematodes were found in $57.8 \%$ and $7.1 \%$ of them, respectively. The intensity of their infection was, for the most part, weak. After being changed to plant nutrition all calves became infected with coccidia and the intensity of their infection underwent a large temporary increase; some animals showed clinical coccidiosis. From large-capacity calf houses a wide spectrum of coccidial and geohelminth species was transmitted to further animal categories including grazing cattle. The most frequently transmitted parasites are highly pathogenic coccidia Eimeria bovis and $E$. zuernii. The intensity of infection was, for the most part, weak.
\end{abstract}

Cattle, large herds, animal category, coccidia, helminths, transfer

Bovine parasites in large herds of cattle in the Czechoslovak Federative Republic have been considerably affected by veterinary measures and modern animal husbandiry and animal hygiene practices conducted there for several years. Helminthoses are now present mainly in the subclinical form (Hovorka and Corba 1984). In his study on gastroenterohelminthoses Chroust (1967) pointed out that ${ }^{\text {‘c } . . . ~ b e s i d e s ~ c l i n i c a l l y ~ d i s e a s e d ~ a n i m a l s ~ i t ~ i s ~ m a i n l y ~ t h e ~ p r e s e n c e ~ o f ~ a s y m p-~}$ tomatic conditions which can worsen and accelerate processes of another aetiology, impair the immunity to infectious diseases and exert serious adverse effects on general performance of the animals"2. According to Supperer (1973), a. o.,helminth larvae parasitizing in the alimentary tract of calves may activate, in the process of their migration, latent viral and bacterial infections of the respiratory tract. In recent years the interest in helminthoses in our country receded and it has become necessary to pay more attention to coccidiosis.

The danger of coccidiosis was pointed out by Zajíček (1962) as early as the first large-capacity calf houses in our country were being designed. Put into operation, these large-capacity calf houses gave rise to conditions favourable to coccidia which infect calves very soon after birth (Bejšovec 1985, 1986). Pavlásek (1985) found coccidia in barns housing dams. Coccidia cause mortality among calves and decrease their body mass, on average, by 12 to $20 \mathrm{~kg}$ (Chroust 1966). According to Papáček and Pavlásek (1984) the body mass of coccidia-infected calves was decreased by 10 to $50 \%$. Bedrnik et al. (1980) drew attention to the role of coccidia in the pathogenesis of diarrhoeal diseases among calves. Chroust (1964) examining dead calves found bronchopneumonia as a complication of coccidiosis. According to Menšik et al. (1984), a.o., the morbidity and mortality of calves kept under intensive husbandry conditions are generally the result of synergic action of many microorganisms. 
On small farms calves are mostly grown in the herds where they were born. Under intensive husbandry conditions animals are often transferred from one place to another. Cerný and Bukvaj (1983), in their study on energy metabolism of such animals, have found that the adaptation of animals to new conditions and regrouping constitute a heavy load. Transfer of animals also increases the possibility of transmission of various pathogens. In the present study we tried to assess the penetration of coccidia and helminths into different categories of cattle.

Some parasite species may be transmitted to large herds of cattle from free-living ruminants. In consequence of collectivization in our country the roe deer Capreolus capreolus $L$. spread to farm ands. The "field ecotype" Capreolus capreolus then developed by adaptation to new biocoenoses. Our study was therefore extended to cover roe deer living on farm lands.

\section{Materials and Methods}

Coprological examination for pneumohelminths was carried out with Baermann's method and that for flukes with Breza's flotation-sedimentation method. The infection with gastroenteronematodes and coccidia was assessed qualitatively according to Breza (1957) and quantitatively according to Breza and Śvarc (1968). The methods are described in detail in a manual entitled Veterinární laboratorní vyšetřovací metody (1975). Considerable time was devoted to each examination so that even weak infections, which may pass unnoticed, under routine diagnostic practices, could be demonstrated. The determination of helminth species was also based on necropsy findings.

A total of 14069 animals were examined in large herds of cattle in Central Bohemia. The numbers of animals examined in 8 different categories are given in Results under points (1) to (8). The same figures are used in histograms to designate the bars illustrating the parasitization of the 8 animal categories, from calves in calving houses to grazing cattle, with the respective coccidial and helminth species. Moreover, 650 roe deer feeding mainly on fodder plants in an agricultural area near Skvorec, about $20 \mathrm{~km}$ to the east of Prague, were examined with the same methods as described above.

\section{Results}

The following 8 bovine categories were examined:

(1) Calves in calving houses. Of 2084 calves examined $38.6 \%$ were parasitized with coccidia and $2.5 \%$ with gastroenteronematodes.

(2) Calves after transfer to large-capacity calf houses. Out of 1129 calves examined the proportions of those parasitized with coccidia and gastroenteronematodes increased to $57.8 \%$ and $7.1 \%$, respectively.

(3) Calves housed in large-capacity calf houses up to 6 months of age. Out of 4612 calves examined the proportins of those infected with coccidia and gastroenteronematodes rose to $72.4 \%$ and $10.9 \%$, respectively.

(4) Young cattle between 6 and 12 months of age. Out of 4375 animals examined $69.8 \%$ were parasitized with coccidia and $18.9 \%$ with gastroenteronematodes.

(5) Heifers between 14 and 19 months of age. Out of 300 animals examined $86.7 \%$ were parasitized with coccidia and $4.0 \%$ with gastroenteronematodes.

(6) Dams of calves. Out of 669 animals examined $97.2 \%$ were infected with coccidia and $38.1 \%$ with gastroenteronematodes. One dam harboured the tapeworm Moniezia sp.

(7) Nursing cows. Out of 200 animals examined $94.5 \%$ were infected with coccidia and $29.5 \%$ with gastroenteronematodes.

(8) Grazing cattle." Out of 700 animals examined $92.7 \%$ were infected with coccidia and as many as $61.7 \%$ with gastroenteronematodes.

From the afore-mentioned findings it can be seen that the highest proportion of coccidia-infected animals was found among dams. New calving houses become contaminated by the first crop of pregnant cows. Evaluation of the data by analysi- 

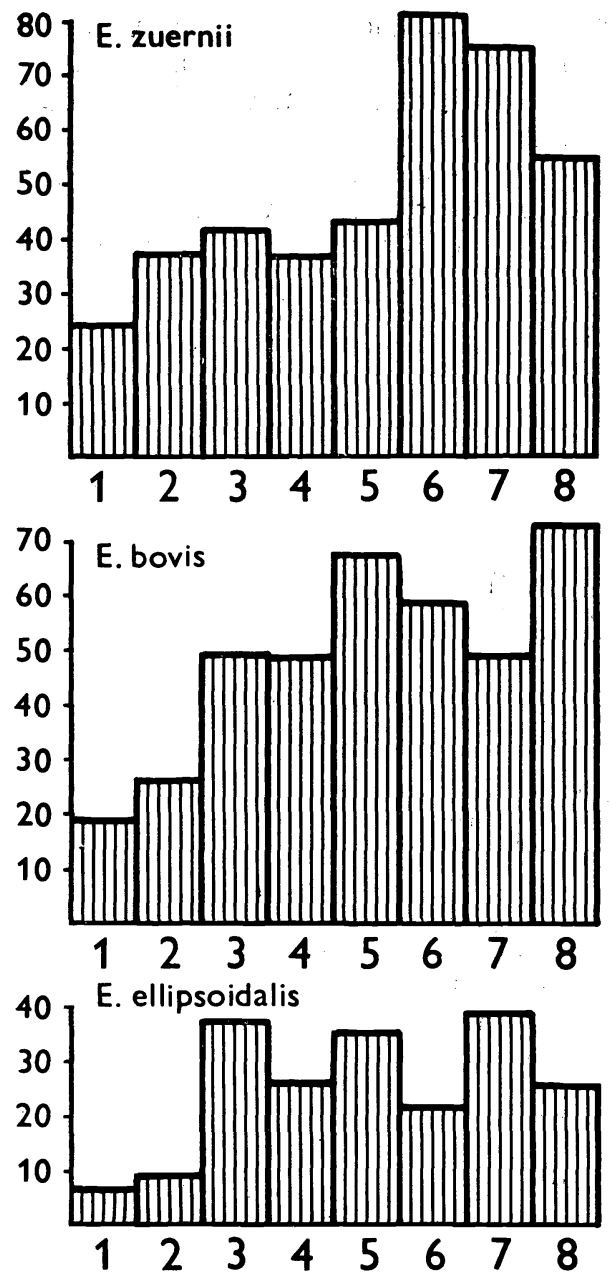

Fig. 1. Figures at the vertical axis designate the percentages of parasitized animals.

Figures under the histogram bars designate the following categories of animals: (1) calves in calving houses; (2) calves after transfer to large-capacity calf houses; (3) calves in largecapacity calf houses up to 6 months of age; (4) young cattle; (5) heifers; (6) dams; (7) nursing cows; (8) grazing cattle. The figures correspond to those of the 8 paragraphs at the beginning of Results where the numbers of animals examined and the proportions of those infected with coccidia and helminths are specified.
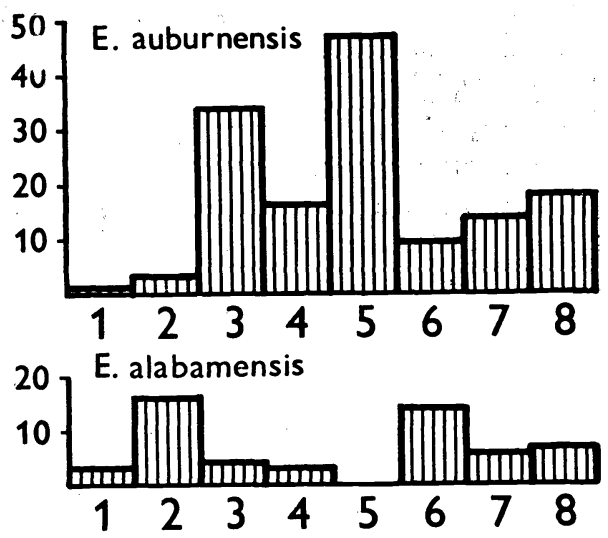

5 E. brasiliensis

$\begin{array}{llllllll}1 & 2 & 3 & 4 & 5 & 6 & 7 & 8\end{array}$
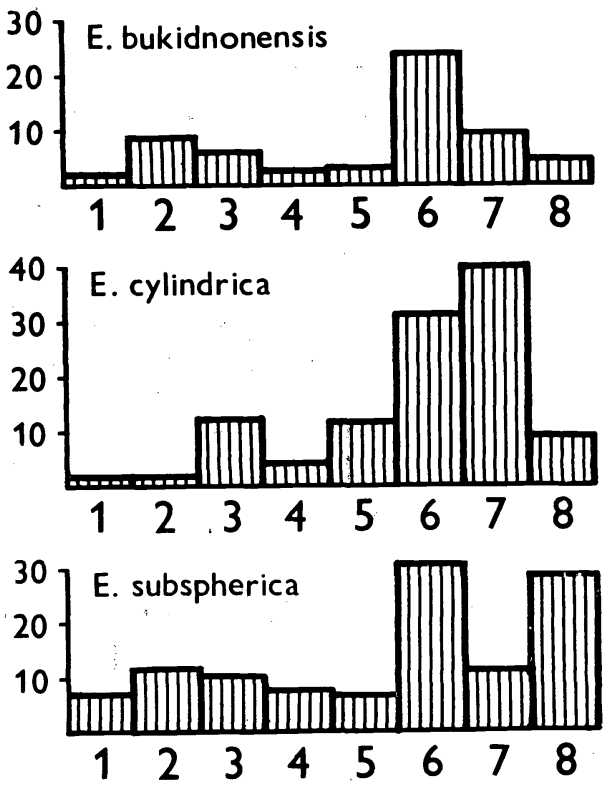

Fig. 2. For legend see Fig. 1. 
of variance revealed no significant differences in the incidence of individual endoparasite species between old and new calving houses. A significant difference $(\mathrm{P}<0.05$ and $\mathrm{P}<0.10)$ was found only in sporadically occurring Eimeria wyomingensis which were not detected in new calving houses.

The dams excreted 10 species of coccidia and 12 genera of gastroenterohelminths (histogram bars above figures 6). The endoparasite species detected in the dams agreed with those found in their calves (histogram bars above figures $1,2,3$ ).
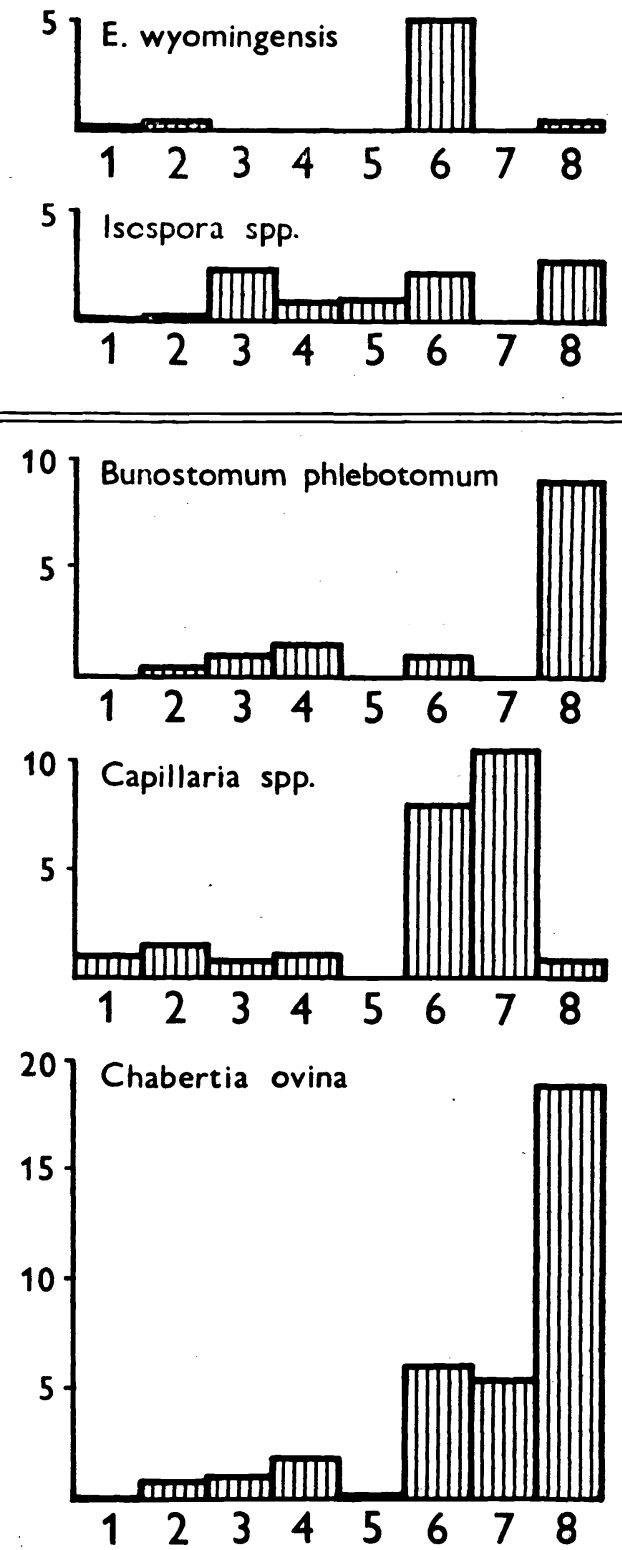

Fig. 3. For legend see Fig. 1. 
Calves become infected mostly by licking various surfaces and by sucking milk from their dams or nursing cows. In some cases infection is caused by inadequate cleansing of the mouth upon post-parturient treatment and by insufficient treatment of the calves, particularly on Sundays and when animal attendants are changed and at night parturitions. Where cows in some calving houses without bedding are considerably dirty, the hygiene of calving is a problem and the environment is contaminated. The most frequently infected calves were those housed together

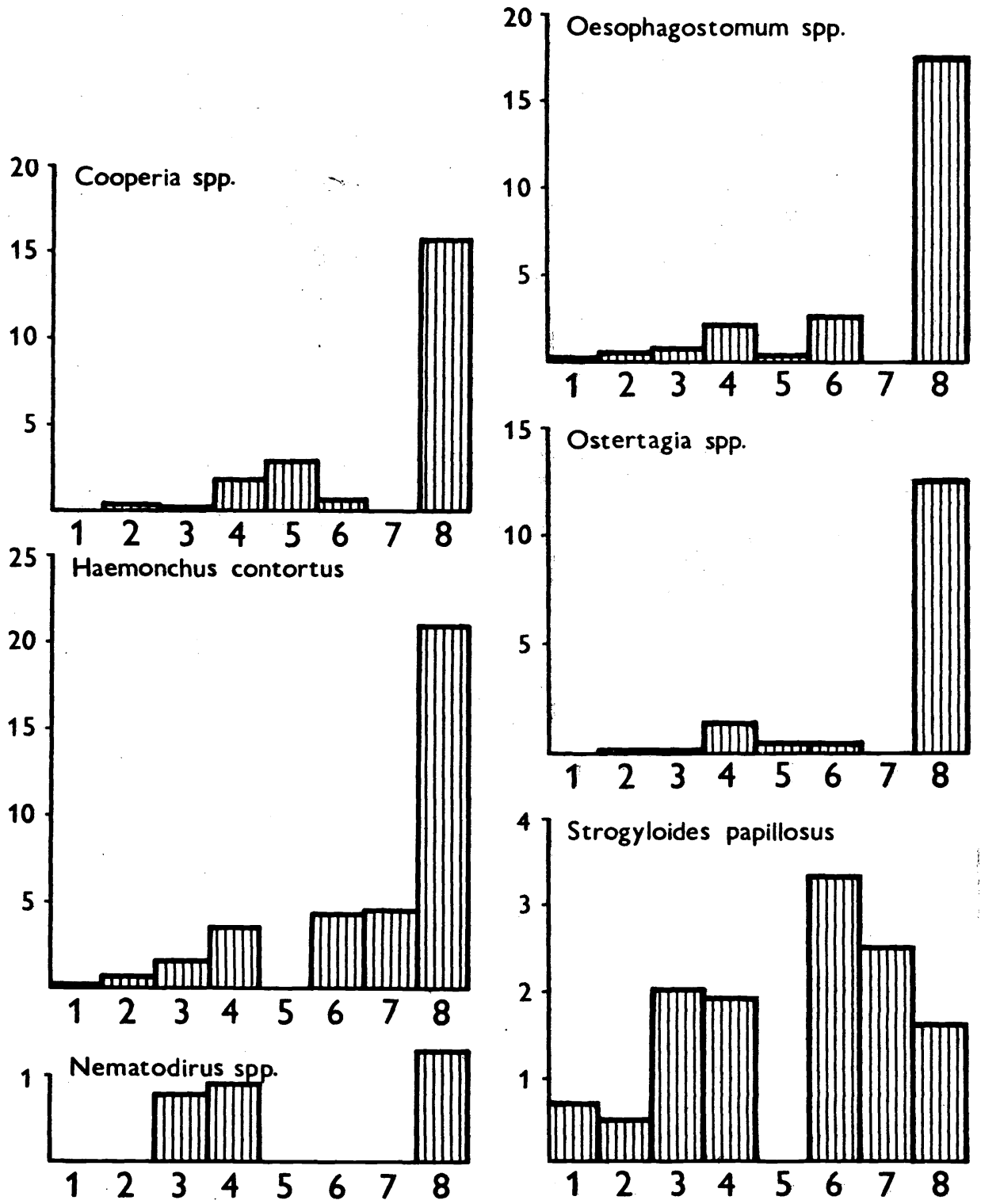

Fig. 4. For legend see Fig. 1.

Fig. 5. For legend see Fig. 1. 
with the dams. Calves housed individually in cages or in stanchion pens were infected sporadically.

Calves arriving to large-capacity calf houses from extensive catchment-areas bring along a wide spectrum of endoparasite species. Thus the proportion of infected animals increases, while the intensity of infection remains weak. After the change from milk nutrition to plant nutrition the proportion of animals infected with coccidia increases to $100 \%$, the intensity of the infection shows a high temporary increase and clinical coccidiosis is often observed. From large-capacity calf houses endoparasites and particularly coccidia are transmitted, step by step, to all the remaining animal categories.

Coccidia were found to occur not only in barn environments but also in grazing cattle where they were detected in $92.7 \%$ of the animals examined (histogram bars above figures 8). Compared with animals kept under various housing practices the prevalence of gastroenteronematodes in grazing cattle was much higher: Haemonchus contortus was found in $21.1 \%$, Chabertia ovina in $19.1 \%$, Oesophagostomum radiatum in $17.6 \%$, Cooperia spp. in $15.6 \%$ Trichostrongylus spp. in $14.0 \%$, Ostertagia spp. in $12.7 \%$, Bunostomum phlebotomum in $9.0 \%$, Trichocephalus ovis in $1.7 \%$, Strongyloides papillosus in $1.6 \%$, Nematodirus spp. in $1.3 \%$ and Capillaria spp. in $0.9 \%$ of the grazing cattle examined. The largest parasite species spectrum is maintained on pasture land.

Our study conducted on cattle ranging from newborn calves to the oldest age categories provided evidence of the continuity of transmission of endoparasites and their permanent circulation in cattle kept under intensive husbandry conditions. Comparison of the findings of coccidia and helminths between the 8 categories was made by analysis of variance. Using Scheffe's method significant $(\mathbf{P}<0.01)$ differences were found only in the infection with helminths between animals housed in buildings and those on pasture.

Grazing cattle may also become infected with some helminth parasites of free-living ruminants. Out of 650 roe deer (Capreolus capreolus L.) examined the following proportions of the animals were infected with helminths that paratisize also in cattle: $46.8 \%$ with Chabertia ovina, $14.2 \%$ with Trichuris ovis, $6.8 \%$ with Haemonchus contortus, $5.4 \%$ with Dictyocaulus viviparus and $0.5 \%$ with Moniezia benedeni. The intensity of their infection was generally weak.

In large herds of cattle kept under intensive husbandry conditions we have to take into account permanent transmission of endoparasites, particularly highly pathogenic Eimeria bovis and E. zuernii. They manifest themselves in animals weakened by various influences. After weaning, in particular, clinical coccidiosis can be expected.

\section{Discussion}

Our examinations of cattle for coccidia and geohelminths were carried out in large bovine herds. The only finding of a biohelminth dependent upon intermediate host (tapeworm Moniezia spp.) was made in one cow out of 14069 animals examined. From our results it appears that barn environments favour the development of coccidia and geohelminths also in winter. The temperature at central-heating radiators is favourable to the sporulation of coccidial oocysts and to the development of helminth larvae.

The high stocking density in large herds is accentuated by the animals themselves. Calves penned in groups rest closely to one another (Kovalčík et al. 1977). 

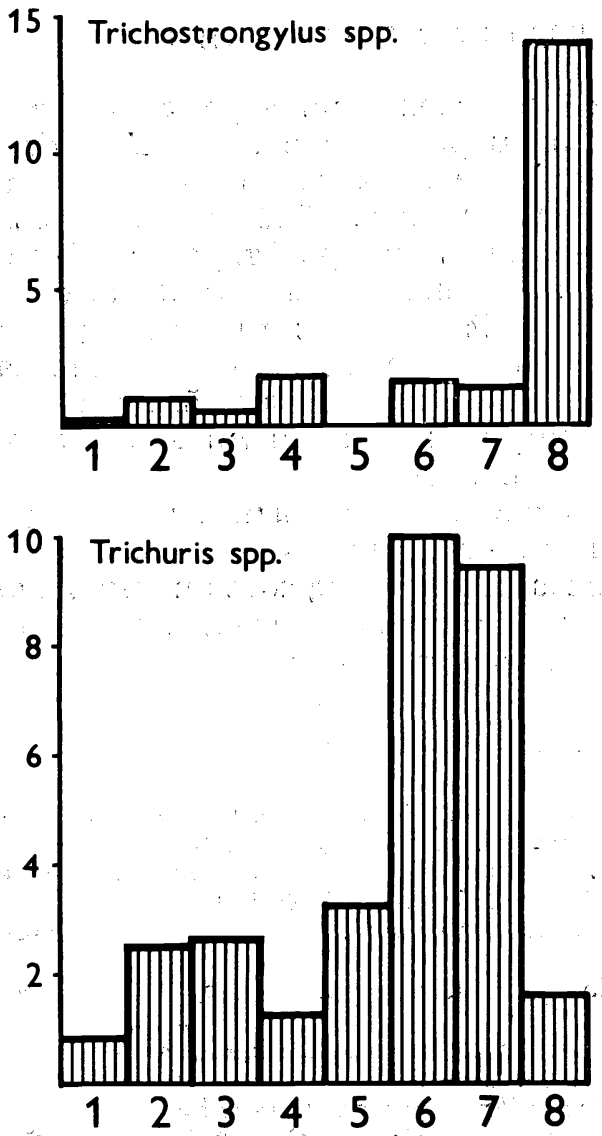

Fig. 6. For legend see Fig. 1 .
The tendency of cows to cluster on pasture was described by Stricklin (1983), Kotvas and Vravák (1984) a.o. Věřís and Navrátil (1982) have reported that calves lick one another from the first post-natal day, particularly if they are penned together after birth. Diarrhoeic calves, in particular, lick various surfaces most intensely. From our observations it appears that animal behaviour plays a major role in the transmission of endoparasites also under intensive husbandry conditions (Bejšovec 1986).

Under intensive husbandry practices it is very difficult to remove coccidial oocysts and helminth eggs from barn surfaces and from animals which are often shifted from one place to another. Endogenous stages of endoparasites in the prepatent period cannot be detected by even very careful coprological examination.

It has often been claimed that parasites are transmitted to cattle from game, particularly from roe deer. In our study the lung nematode Dictyocaulus viviparus was found in $5.4 \%$ of the roe deer examined but in no instance in cattle. Gastroenteronematodes found in roe deer were detected as frequent parasites of cattle also in barns under intensive husbandry practices (histogram bars 1 to 7). Considering the presented evidence of permanent transmission of endo-

parasites by cattle the role of possible transmission of gastroenterohelminths from roe deer seems of practically little importance.

\section{Permanentní přenos endoparazitů ve velkochovech skotu}

Budovy poroden a profylaktorií jsou kontaminovány již prvním zástavem zvírat. Analýzou rozptylu nebyla prokázána statistická významnost rozdílu výskytu druhů endoparazitů ve starých a nových porodnách. $97,2 \%$ matek vylučovalo oocysty kokcidii, 38,1\% vajička gastroenteronematodú. Telata se infikovala malým množstvím endoparazitů. Po převezení do velkokapacitních teletníků byly zjištěny kokcidie u $57,8 \%$ a gastroenteronematodi u $7,1 \%$ telat. Intenzita infekce byla u prrevážné většiny telat velmi slabá. Po převedení na rostlinnou výživu se infikují kokcidiemi všechna telata, přechodně se silně zvyšuje intenzita infekce. $U$ některých telat se projevuje klinická kokcidióza. $Z$ velkokapacitních teletníkủ je přenášeno široké spektrum druhů kokcidií a geohelmintů do všech dalších kategorií zviŕat i na pastviny. Nejvíce jsou přenášeny silně patogenní kokcidie Eimeria bovis a $E$. zuernii. U převážné většiny zviŕat je intenzita infekce slabá. 


\section{Перманентный перенос эндопаразитов в скотоводстве}

Объекты родильных помещений и профилакторий заражаются уже при первой загрузке животных. Анализом рассеивания не была установлена статистическая значимось разности наличия видов эндопаразитов в старых и новых родильных помещениях. 97,2 \% маток выделяли ооцисты кокцидий, $38,1 \%$ - яички гастроэнтеронематодов. Телята были инфицированы небольшим количеством эндопаразитов. После перевода в телятники были у 57,8 \% телят выявлены кокцидии и у 7,1 \% - гастроэнтеронематоды. У преобладающехо большинства телят интенсивность инфекции была весьма незначительной. После перевода на растительную пищу инфицируются кокцидиями все телята. временно быстро увеличивается интенсивность инфекции. У некоторых телят проявляется клинический кокцидиоз. Из телятников передается широкий спектр видов кокцидий и геогельминтов в остальные категории животных и на пастбища. Больше всех передаются интенсивно патогенные кокцидии Еимериа бовис и Е. зуернии. Интенсивность инфекции у преобладающего большинства животных слабая.

\section{References}

BEDRNIK, P.-JURKOVIC, P.-ŠEVČfK, B.-FIRMANOVÁ, A.: Možnosti prevence kokcidiózy telat ve velkokapacitnich teletnících Clopidolem. Veterinářství, 30, 1980: 24-26

BEJŠOVEC, J.: Ekoetologické přičiny perzistence a přenosu endoparazitủ v podmínkách velkovýrobního zemědělství. Vysoká škola zemědělská VN MON, Prague, 1985, 170 p.

BEJSOVEC, J.: The infection of calves by endoparasites in calving pens and calf houses. Acta vet. Brno, 55, 1986: 197-206

BEJSOVEC, J.: Ethological aspects of transmission of coccidia in cattle. Society of Protozoologists Abstracts, 1986: 214

BREZA, M.: Niekolko praktických poznatkov a námetov $\mathrm{k}$ helmintokoprologickej diagnostike. Helmintológia. Sborník prác SAV Bratislava, 1, 1957: 57-63

BREZA, M. - SVARC, R. : Eine einfache Methode zur Bestimmung der Einzahl gastrointestinaler Strongylaten in den Faeces der Wiederkäuer. Studia Helmintol. Košice, 2, 1968: 89-98

CHROUST, K.: Kokcidióza u telat. Sborník Vysoké školy zemědělské v Brně, ř. B: Spisy fakulty veterinárni, 12, 1964: 209-233

CHROUST, K.: Kokcidie a kokcidiózy v chovech telat. Veterinářství, 16, 1966: 63 - 65

CHROUST, K.: Kritické hodnocení současných poznatkú $v$ terapii gastroenterohelmintóz u přežvýkavců. Veterinaria SPOFA, 9, 1967: 207-218

CERNY, M. -BUKVAJ, J.: Vliv teploty prostředí a přesunư zvířat na energetický metabolismus telat. Náš chov, 44, 1983: 289-291

HOVORKA, J.-CORBA, J.: Vplyv dehelmintizácie na hmotnostné prírastky a úžitkovost́ pri subklinických helmintózách zvierat. Veterinářství, 34, 1984: 222-223

KOTVAS, R.-VAVAK, V.: Správanie sa dojníc na intenzivnej pastve. Polnohospodárstvo, 30, 1984: 228-326

KOVALČIK, K.-KOVALC̆IKOVA, M.-BRESTENSKÝ, V.: Výskum etológie teliat v rôznom ustajení. Project report, VÚŽV Nitra, 1977

PAPÁCEK, J.-PAVLÁSEK, I.: Ekonomický př́nos tlumeni kokcidiózy telat ve VKT Stará Hlína. Veterinářství, 34, 1984: 32-33

PAVLÁSEK, I.: Výsledky výzzumu kokcidií u skotu. Souhrny přednášek 40 let rozvoje československé parazitologie C. Budějovice 1985: 18

STRICKLIN, W. R.: Matrilinear social dominance and spatial relationships among Angus and Hereford cows. J. Anim. Sci. 57, 1983: 1397-1405

SUPPERER, R.: Parasitosen der Kälber. Tierärztl. Praxis, Münch. 1, 4, 1973: 403-412

VĚ̉is, J. - NAVRATIL, J.: Chování telat v období po porodu v závislosti na zpưsobu ustájení. Sbornik Vysoké školy zemědělské v Praze AF, řada B, 37, 1982: 109-124

ZAJfCEK, D.: Epizootologie kokcidiózy telat. Informační zprávy pro veterinární a zemědělskou praxi SPOFA, 20, 1982: 7-12 